\title{
CARACTERIZAÇÃO GEOLÓGICA E ESTRUTURAL ATRAVÉS DA INTERPRETAÇÃO DO PRODUTO INTEGRADO TM-LANDSAT 5 E DADOS AEROGAMAESPECTROMÉTRICOS, REGIÃO DE ALTA FLORESTA - MT
}

\author{
Vanessa Madrucci, ${ }^{1}$ Paulo Veneziani, ${ }^{2}$ Waldir Renato Paradella ${ }^{3}$ \\ Recebido em 10 out. 2003 / Aceito em 18 jun. 2004 \\ Received oct. 10, 2003 / Accepted jun. 18, 2004
}

\begin{abstract}
This paper deals about the geological, tectonic and structural characterization in the Alta Floresta Gold Province region, MT, through the digital integration of TMLandsat and gamma ray spectrometry data (total count). The total count - TM integrated product has the essential features for geological interpretation. This product shows structural features from the drainage pattern and relief elements (TM image) and shows the radiometric values (RGB) that contribute to the differentiate lithostructural units. The geological map was composed based on the total count radiometric values interpretation (considering the topography and anthropogenic interference on the radiometric response), in the relief and drainage patterns features (TM image) and field data. Considering the intense anthropogenic activities in the area and almost flat terrain (that prejudice the geological interpretation of remote sensing image), the integrated products generation (TM-gamma) was decisive to the obtention of indispensable data to the mapping. The final product was the geological map of area, in the 1:250.000 scale, with delimited 10 lithostructural units, directly related to radiometric units and structural features. In addition, remarkable N60-70W trend strike-slip systems (ductile and ductile brittle shear zones) were detected and characterized through visual interpretation of the integrated products and field verification.
\end{abstract}

Keywords: TM-Landsat 5, airborne gamma ray data, fotointerpretation, geological map, Alta Floresta region.

\section{RESUMO}

Este artigo apresenta a caracterização geológica e tectono-estrutural de uma região da Província Aurífera de Alta Floresta, Mato Grosso, através da interpretação do produto integrado TM-Landsat 5 e de dados aerogamaespectrométricos (contagem total). 0 produto integrado TM-contagem total possui características importantes para a interpretação geológica: apresenta num único produto, feições estruturais fornecidas pela imagem TM, representadas pelos elementos de relevo e drenagem e os valores radiométricos (RGB) que contribuem de forma bastante satisfatória na discriminação das unidades litoestruturais. A geração do mapa geológico foi baseada na interpretação dos valores radiométricos de contagem total (levando-se em consideração quais fatores, tais como topografia e atividade antrópica, poderiam influenciar a reposta radiométrica), nas feições de relevo e drenagem (que auxiliam na caracterização tectono-estrutural) fornecidas pela imagem TM e também nos dados de campo. Como a área apresenta intensa atividade antrópica e relevo muito arrasado, o que prejudica a interpretação geológica das imagens de sensoriamento remoto, a geração do produto integrado TM-contagem total foi decisiva para a obtenção de dados necessários ao mapeamento. Como resultado final foi elaborado o mapa geológico da área, em escala 1:250.000, sendo delimitadas 10 unidades litoestruturais relacionadas diretamente às unidades radiométricas e às feições estruturais. Um importante trend de direção N60-70W e altos mergulhos relacionados às zonas de cisalhamento transcorrentes sinistrais dúcteis a dúcteis rúpteis foi caracterizado através da interpretação visual de produtos integrados e dados de campo.

Palavras-chave: TM-Landsat 5, dados aerogamaespectrométricos, fotointerpretação, mapa geológico, Alta Floresta.

\footnotetext{
Instituto de Geociências - Universidade de São Paulo - Rua do Lago, 562 Cidade Universitária - CEP: 05508-900 São Paulo - SP - Tel: (11) 96771162 Fax: (11) 30914129 E-mail: madrucci@usp.br

2 Instituto Nacional de Pesquisas Espaciais - INPE - Av. dos Astronautas 1758 Jardim da Granja - CEP: 12227-010 São José dos Campos - SP - Tel: (12) 39456445 Fax: (12) 3945 -6488 E-mail: paulo@ltid.inpe.br

3 Instituto Nacional de Pesquisas Espaciais - INPE - Av. dos Astronautas 1758 Jardim da Granja - CEP: 12227-010 São José dos Campos - SP - Tel: (12) 3945-6446 Fax: (12) 3945-6488 E-mail: waldir@ltid.inpe.br
} 


\section{INTRODUÇÃOO}

A Província Aurífera de Alta Floresta é uma região com elevado potencial mineral, porém com poucos estudos geológicos e mapeamentos, devido principalmente à falta de acessos terrestres. Existe a necessidade de se estudar a geologia da região, bem como de se compreender sua evolução tectônica e estrutural para que esta província possa ser melhor explorada, principalmente em relação às ocorrências de depósitos auríferos primários.

As técnicas de sensoriamento remoto auxiliam o estudo geológico e tectono-estrutural dessas regiões de difíil acesso e pouco conhecidas, devido à sua visão sinóptica, otimizando tempo e custos, bem como a possibilidade de integração de dados multifontes, neste caso TM-Landsat 5 e aerogamaespectrometria (contagem total).

Existem várias técnicas para combinar dados digitais multifontes: transformações estatísticas (análise canônica, componentes principais e decomposição wavelet), aritméticas, e as transformaç̃óes visuais de cores no monitor de vídeo - como a IHS (Intensity-Hue-Saturation). Harris e outros (1994) avaliaram as seguintes técnicas digitais de integração de dados: combinação de bandas, combinações aritméticas, transformaçōes estatísticas e transformação IHS. Nesta avaliação foram utilizados como fatores qualitativos a interpretabilidade de cores, a variação de cores e a efetividade de integração. Harris e outros (1994) concluíram que a transformação IHS é a técnica mais flexível e que apresenta 0 melhor desempenho para a combinação e integração de dados geológicos multifontes, pois permite manipular separadamente os canais de intensidade, matiz e saturação nas imagens.

Dessa forma, a transformação IHS tem sido muito utilizada em estudos geológicos, principalmente na integração de dados aerogeofísicos e imagens de satélite (MATHER, 1987; HARRIS; MURRAY; HIROSE, 1990, HARRIS et al., 1994; RENCZ; RYERSON, 1999).

A utilização de produtos integrados TM e aerogeofísicos gamaespectrométricos tem apresentado bons resultados na discriminação de unidades geológicas (HARRIS et al., 1994; DIAS; PARADELLA, 1997; MADRUCCI, 2000, OKIDA, 2001), principalmente em áreas pouco conhecidas geologicamente, como a região amazônica. A vantagem da utilização de produtos integrados Landsat-aerogamaespectrométricos no mapeamento geológico é que estes apresentam realces das feições estruturais de relevo e drenagem representadas na imagem TM e também variações de matizes que representam as respostas gamaespectrométricas. Dessa forma, a interpretação geológica é realizada em uma única imagem, onde as variações de matizes representam as respostas radiométricas que estão relacionadas ao tipo de rocha e as feições texłurais de relevo são indicativas da estruturação tectônica, au- xiliando na delimitação de contatos litoestruturais. Recentemente têm sido utilizadas técnicas de redes neurais para a interpretação geológica. Entretanto, neste trabalho, utilizou-se o conhecimento do fotointérprete.

$\mathrm{Na}$ etapa de fotointerpretação do produto integrado TM-contagem total, é necessário tomar alguns cuidados, pois as respostas geofísicas gamaespectrométricas são relativas aos materiais que estão nos primeiros 35 centímetros da superfície terrestre, fazendo com que a sua relação com a geologia leve em conta além da rocha, principalmente a química do solo. Além disso, alguns fatores físicos também controlam as respostas radiométricas, tais como relevo, vegetaçacão e atividade antrópica (GUNN et al., 1998).

Para verificar se a atividade antrópica e o relevo influenciam as respostas radiométricas na área de estudo, realizou-se uma análise quantitativa, através da comparação entre um perfil gamaespectrométrico (contagem total - cps) e um perfil geológico-topográfico. Dessa maneira, pôde-se analisar se as respostas radiométricas estavam relacionadas somente com a litologia ou se outros fatores influenciavam tais respostas, de modo que o mapa geológico pudesse ser ainda mais confiável.

Dessa forma, este artigo objetiva mostrar a eficiência e a importância da fotointerpretação de produtos integrados TM-gama para 0 mapeamento geológico e tectono-estrutural de áreas de difíicil acesso, principalmente na região amazônica, auxiliando nas pesquisas geológicas e nas investigações de caráter prospectivo.

\section{LOCALIZAÇÃO E GEOLOGIA DA ÁREA DE ESTUDO}

A área de estudo localiza-se na região norte do Estado do Mato Grosso, e está inserida na porção sul-sudeste do Cráton Amazônico, fazendo parte da Província Rio Negro-Juruena (TASSINARI; MACAMBIRA 1999). Nela ocorrem rochas de idades paleoproterozóicas a mesoproterozóicas e aluviões recentes. Lacerda Filho e outros (2001 a) apresentam resultados de datações na área de estudo e admitem a existência de dois domínios crustais distintos na região norte do Mato Grosso: 0 Domínio Acrescionário Deformado (DAD) e o Domínio Granito-Vulcânico (DGV). 0 primeiro é formado por rochas supracrustais e corpos plutônicos submetidos a metamortismo de médio a alto grau e deformação dúctil acentuada e 0 segundo constitui um cinturão de rochas plutônicas e vulcânicas, pouco deformadas de caráter calci-alcalino, com composições dioríiticas a graníticas. Segundo os autores, as suítes são intrusivas em gnaisses polideformados, localmente migmatizados e que são correlacionáveis aos gnaisses do Complexo Cuiú-Cuiú da Província Ventuari-Tapajós.

No DAD estão presentes os Complexos Bacaeri-Mogno, Nova Monte Verde e Tonalito Vitória, de idade paleoproterozóica (LACERDA FILHO et al., 2001a). 0 primeiro é composto por rochas supracrustais 
metamorfisadas em médio a alto grau, incluindo anfibolitos, dioritos, metagabronoritos e metapiroxenitos. Segundo os autores, os anfibolitos desta unidade têm idade de aproximadamente 2,24 Ga e são interpretados como restos de uma sequiência oceânica preservada em meio às rochas mais jovens. 0 Complexo Nova Monte Verde é constituíio por ortognaisses tonalíticos a graníticos, migmatitos e rochas supracrustais representadas por granada-biotita gnaisses, sillimanita gnaisses, rochas calci-silicáticas e anfibolitos (datação U-Pb indica idade de $1774 \pm 28$ Ma). 0 Tonalito Vitória compreende rochas quartzo-feldspáticas, ricas em hornblenda e às vezes ortopiroxênio, com composição tonalítica, diorítica e enderbítica. Datações U-Pb em zircão foram realizadas nas amostras de tonalito e enderbito, apresentando idades de $1770 \pm 9$, $1775+10$ Ma.

Também fazendo parte do DAD e recobrindo discordantemente 0 embasamento, encontra-se a Sequiência Metavulcanossedimentar Cabeça (BARROS; LAET; RESENDE, 1999), de idade paleoproterozóica, constituída por rochas metavulcânicas ácidas a intermediárias, sericita xistos e metacherts. Segundo Lacerda Filho e outros. (2001a), xistos milonitizados desta unidade, datados pelo método U-Pb, mostraram idade de $1859 \pm 5 \mathrm{Ma}$.

0 DGV caracteriza-se por uma grande diversidade de tipos de rochas graníticas e vulcânicas, normalmente exibindo efeitos locais de deformação rúptil a rúptil-dúctil (LACERDA FILHO et al., 2001b). Através de dados isotópicos e geoquímicos LACERDA FILHO e outros (2001b) admitem que este terreno representa um arco magmático Paleoproterozóico de caráter dominantemente juvenil.

Fazendo parte do DGV encontram-se a Suíte Vulcânica Colíder e a Suíte Intrusiva Teles Pires (LACERDA FILHO et al., 2001a; LACERDA FlLHO et al., 2001b). A primeira é constituída por riolitos, riodacitos, andesitos, tufos e brechas, de natureza calci-alcalina que bordejam as partes sul da Serra do Cachimbo e norte da Serra dos Apiacás, formando duas faixas extensas e contínuas com direção NW-SE. Datações U-Pb disponíveis, realizadas respectivamente por JICA/MMAJ' (2000 apud LACERDA FILHO et al., 2001b) e Pinho, Lima e Chemale (1999), indicam idades de $1786 \pm 17$ Ma e $1810 \pm 14$ Ma para as rochas dessa unidade. A Suíte Intrusiva Teles Pires é caracterizada pelos granitos pósorogênicos, porfiríticos, de cor vermelho tijolo, localmente com textura rapakivi e fluorita, intrusivo nas rochas vulcânicas da Suíte Colíder. Segundo Lacerda Filho e outros (2001b), uma datação U-Pb forneceu idade de $1757 \pm 16$ Ma para rochas dessa unidade. Pinho e outros (2001) sugerem que na região norte do Mato Grosso seja adotado o termo Magmatismo Teles Pires (BASEl, 1977), já que as datações U-Pb para essas rochas na região estão entre 1,8 e 1,74 Ga.
NNo Mesoproterozóico, posteriormente ao magmatismo Teles Pires, desenvolveu-se a deposição de sedimentos arcoseanos intracontinentais, arenitos, arenitos arcoseanos e conglomerados que sofreram um metamorfismo de baixo grau, representados na área pela Formação Dardanelos (SILVA et al., 1980). Valente (1998) e Madrucci (2000) subdividiram a Formação Dardanelos em três unidades: unidade 1 constituída por quartzitos, meta-arcóseos e meta-conglomerados, apresentando uma morfologia de cristas alongadas (reflexo da verticalização das rochas em consequiência do cisalhamento transcorrente sinistral); unidade 2 constituída por meta-arenitos, meta-arenitos arcoseanos e conglomeráticos e meta-argilitos; e unidade 3 , formada por quartzitos, meta-arcóseos e meta-conglomerados.

Conforme apresentado anteriormente, LACERDA FILHO e outros (2001a) relacionam a evolução desse segmento do Cráton Amazônico ao desenvolvimento de um arco magmático paleoproterozóico, gerado por subducção de uma placa litosférica oceânica, sob a crosta continental, em regime compressivo. Porém, Leite, Saes e Macambira (2001) admitem a ocorrência de dois importantes períodos de amalgamação ao longo da evolução da porção sudeste do cráton amazônico, um de aproximadamente 1,92 Ga (Orogenia Transamazônica), representado na área pelo Cinturão Metamórfico Juruena, de direção E-W, composto por ortognaisses migmatitos e granulitos com idade de aproximadamente 1,92 Ga, deformados e cavalgados sobre terrenos antigos (2,0 Ga) do Cinturão Granítico Alta Floresta-Peixoto de Azevedo, e a segunda entre 1,75 Ga (idade da Sequiência Teles Pires, que recobre/intrude esses dois terrenos) e 1,35 Ga (idade máxima da sedimentação Dardanelos), estabelecendo a configuração atual do terreno.

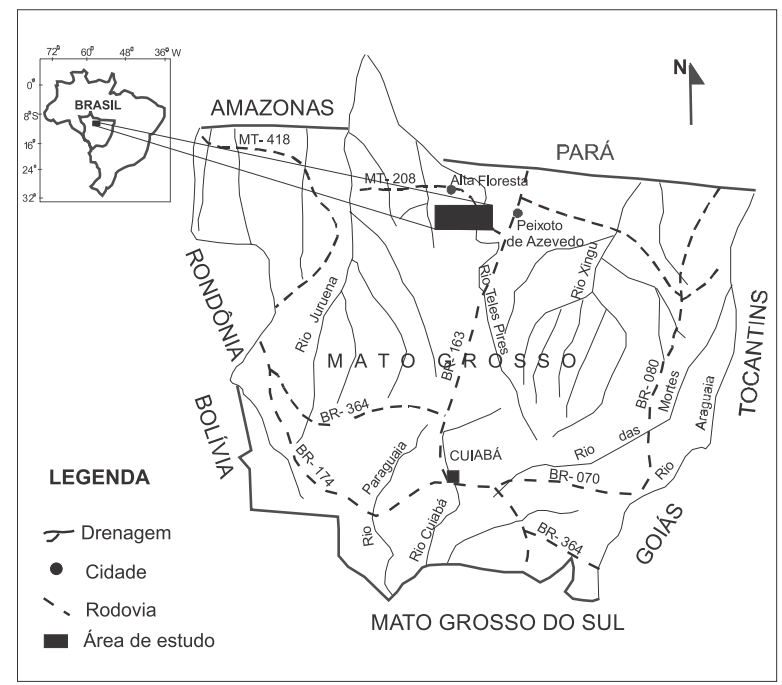

Figura 1 - Localização da área de estudo. Figure 1 - Study area.

1 Japan International Cooperation Agency/Metal Mining Agengy of Japan 


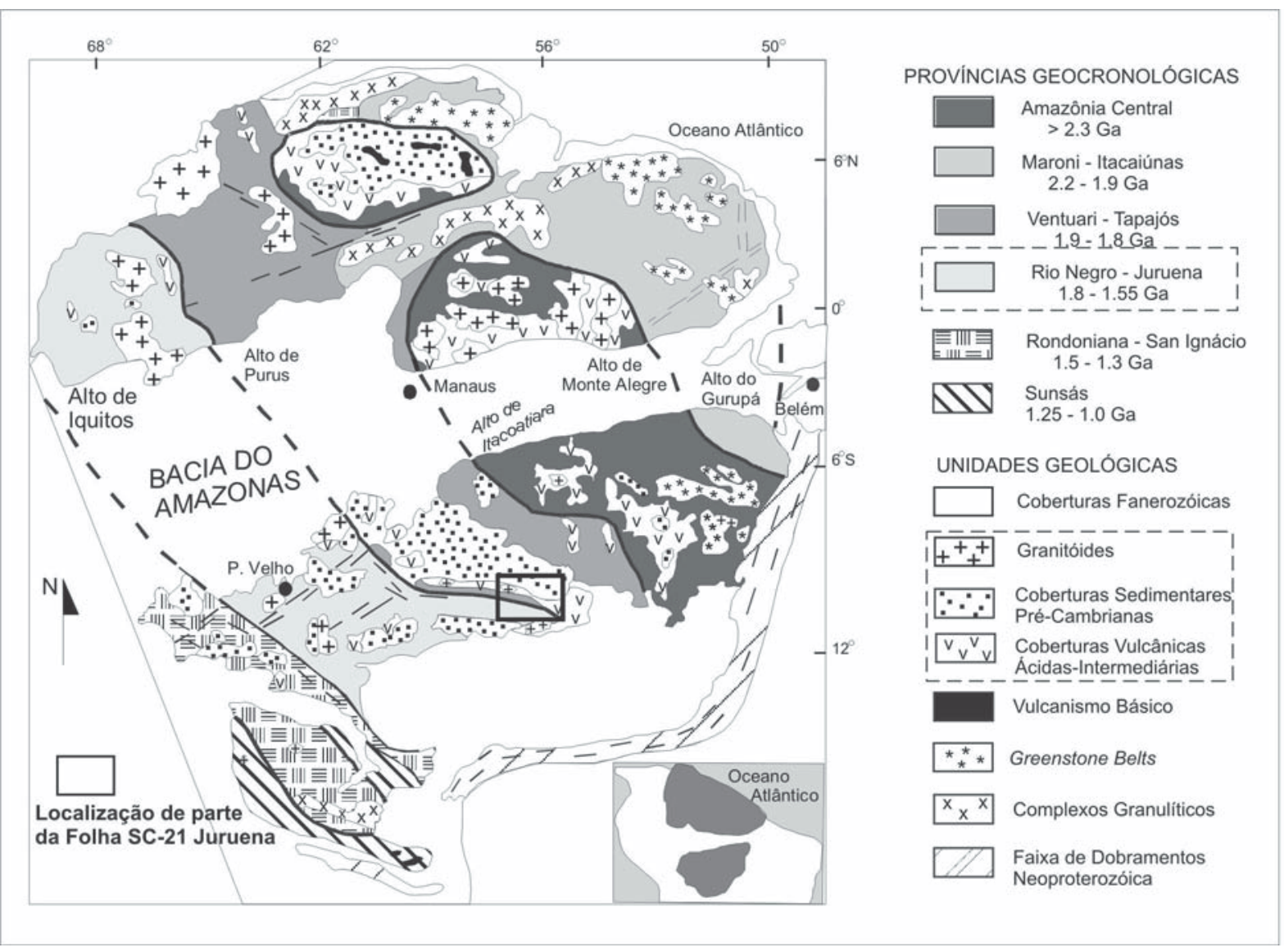

Figura 2 - Províncias geocronológicas do cráton Amazônico (TASSINARI; MACAMBIRA (1999)).

Figure 2 - Geochronological provinces of Amazon Craton (TASSINARI; MACAMBIRA (1999)).

Valente (1998), baseado em fotointerpretações de imagens de satélite e dados de campo, admite que a área de estudo apresenta uma deformação progressiva submetida a vários regimes de cisalhamento (dúctil, dúctil-rúptil), com expressivo evento termo-tectônico, acompanhado de intensa mobilização magmática em escala regional. Este evento está caracterizado por manifestações vulcânicas e intrusões (como por exemplo a Suíte Vulcânica Colíder, a Suíte Intrusiva Teles Pires, Tonalito Vitória, entre outros) e deposição de sedimentos (Formação Dardanelos). A Figura 3 apresenta 0 mapa fotogeológico da área elaborado por Valente (1998).

\section{MATERIAIS E MÉTODOS}

\section{Imagens de satélite}

Utilizaram-se duas imagens TM-Landsat 5, órbita/ponto 227/ 067: em formato digital, (bandas 1, 2, 3, 4, 5 e 7), com data de aquisição 21 de junho de 1984 e uma composição colorida 543 (RGB), em papel, com data de aquisição 23 de junho de 1991. Todas com azimute solar de $50^{\circ}$ e elevação solar de $46^{\circ}$. Foi escolhida a imagem datada de 1984 para a integração com os dados aerogeofísicos, pois, por ser mais 


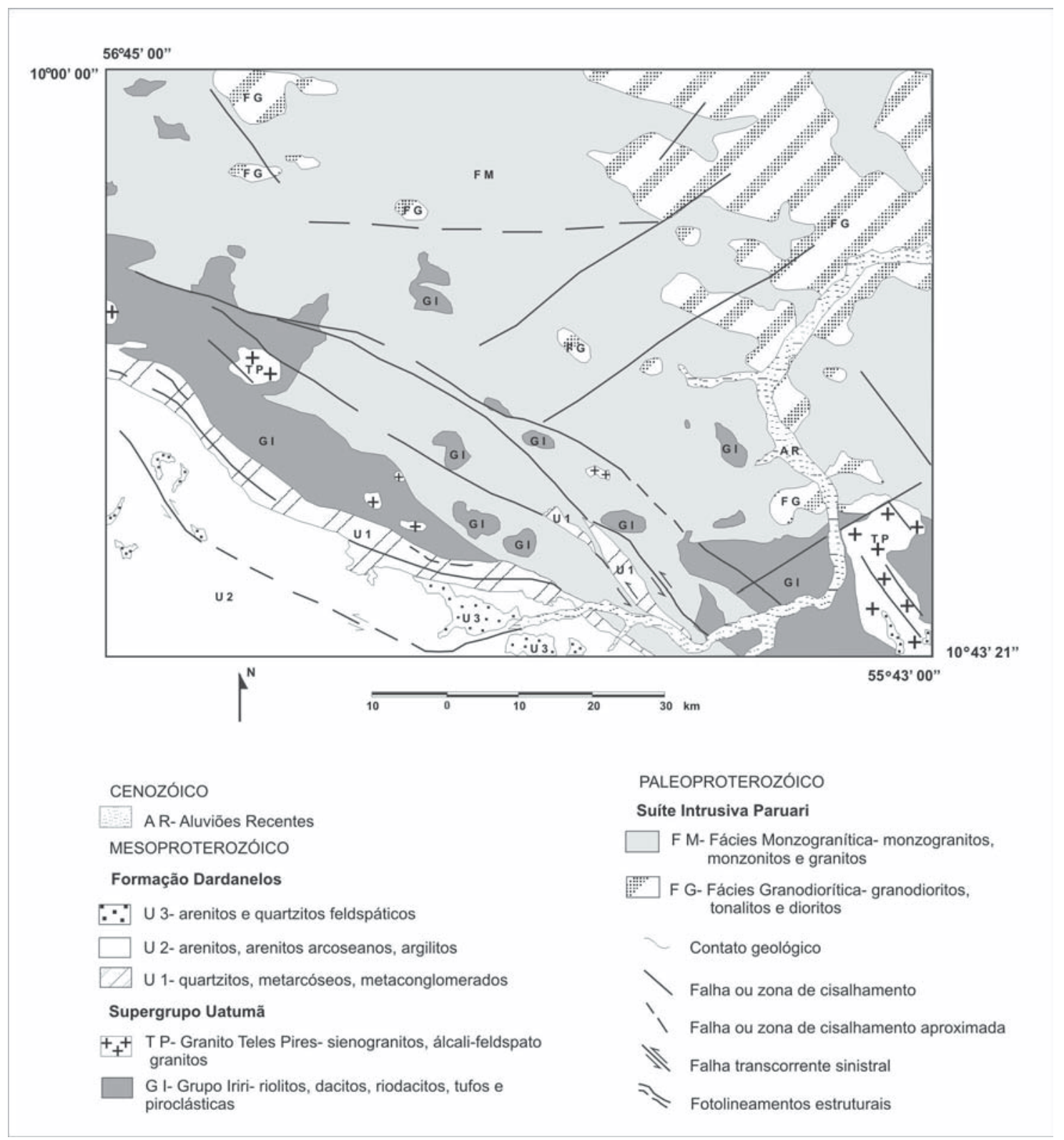

Figura 3 - Mapa geológico da área. (VALENTE, 1988)

Figure 3 - Geological map of area. (VALENTE, 1988) 
antiga apresenta pouca atividade antrópica, de maneira a não prejudicar a interpretação geológica. Foi escolhida a imagem de 1991, para a análise quantitativa entre a resposta aerogamaespectrométrica e os fatores relacionados à topografia e à atividade antrópica, porque apresenta a mesma data do aerolevantamento geofísico.

\section{Dados Aerogeofísicos Gamaespectrométricos}

Utilizou-se o canal de contagem total (CT), em formato ASCII (fornecidos pela Companhia de Pesquisa de Recursos Minerais - (PRM), referente ao aerolevantamento do Projeto Juruena Teles Pires, fases I e II, realizado no período de agosto a novembro de 1991. As direções das linhas de vôo foram N-S, com espaçamento de $2 \mathrm{~km}$ e a altura média do vôo 150 metros. 0 intervalo entre as medições geofísicas sucessivas no terreno é equivalente a 60 metros. Para este trabalho foi escolhida a imagem de contagem total, pois segundo Vasconcellos e outros (1994), esta apresenta maior precisão estatística fornecendo uma correlação maior das unidades radiométricas com as litologias. Os canais de Urânio (U),
Tório (Th) e Potássio (K) também foram utilizados, mas como o canal de contagem total apresentou resultados mais eficientes na discriminação das unidades litológicas, estes não serão apresentados neste trabalho. Detalhes sobre os resultados dos canais U, Th e K para o estudo desta área podem ser encontrados em Madrucci (2000).

\section{Dados de campo}

Utilizaram-se dados de campo na forma de descrições litológicas e medidas estruturais obtidos pelos autores e também fornecidos pela Companhia de Pesquisa de Recursos Minerais (CPRM) e pela Companhia Matogrossense de Mineração (METAMAT).

A abordagem metodológica seguida neste trabalho consistiu nas seguintes etapas: pré-processamento das imagens TM e gama; processamento digital das imagens TM e gama, que envolve o realce e a integração das imagens; e interpretação do produto integrado TM-gama. A Figura 4 apresenta o quadro esquemático do método utilizado.

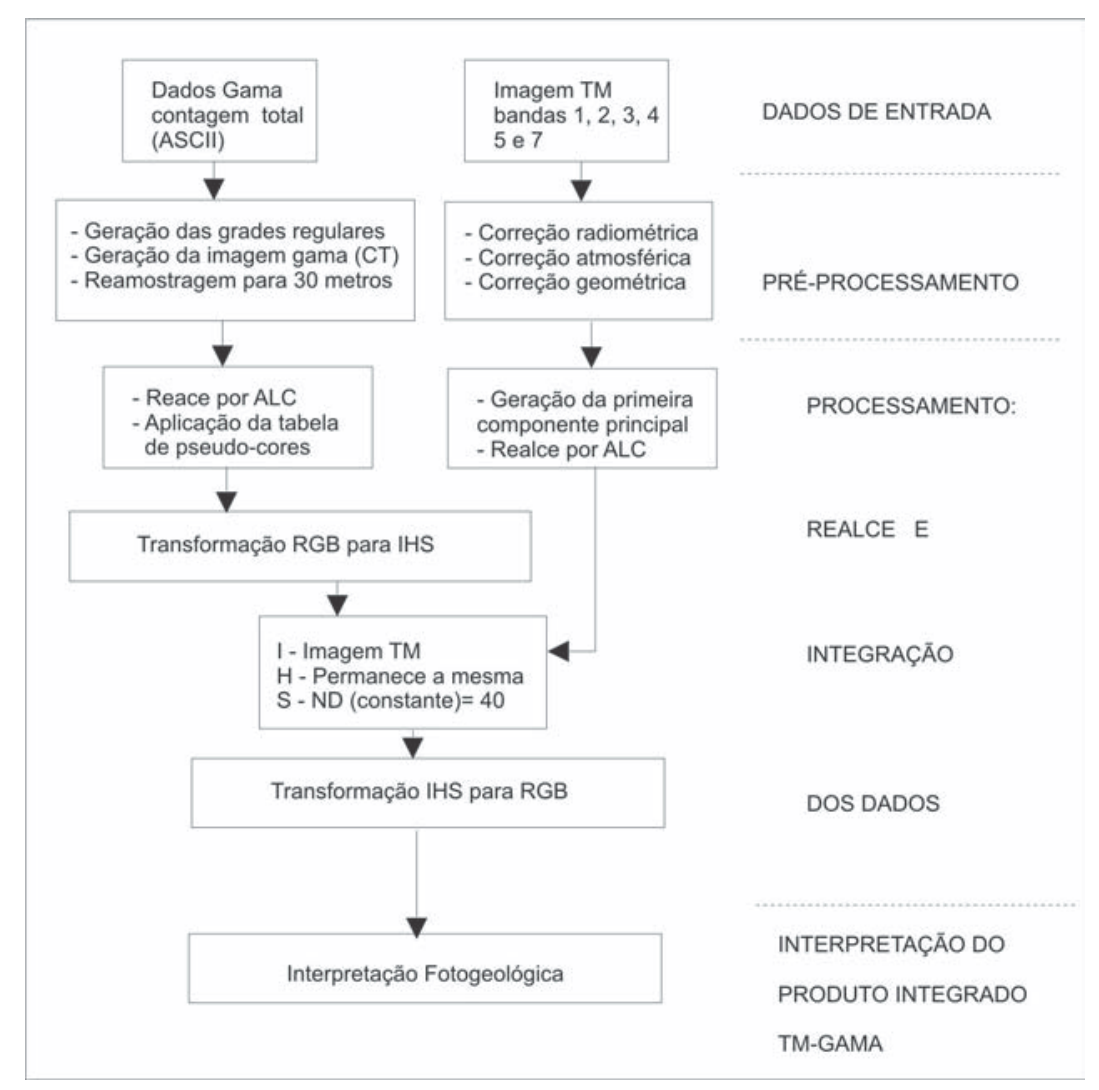

Figura 4 - Quadro esquemático do método utilizado. Figure 4 - Schemetic picture of method. 


\section{Pré-Processamento e Processamento Digital das Imagens}

0 primeiro procedimento realizado foi o pré-processamento da imagem TM e dos dados aerogeofísicos. Na imagem TM foram realizadas correçõoes radiométrica, atmosférica e geométrica (ortorretificação4). Nos dados aerogeofísicos o pré-processamento consistiu nas seguintes etapas: conversão dos dados originais em grades regulares (250 metros); geração da imagem gama (sendo aplicadas nesta imagem filtragens direcionais e de suavização) e reamostragem das células para 30 metros.

Na geração de produtos integrados ópticos e geofísicos é necessário que as imagens estejam com um tamanho de pixel comum. Harris e outros (1994) sugerem que todas as imagens sejam reamostradas para o menor tamanho de pixel possível. Entretanto, isso só é válido ao considerar-se a acurácia geométrica dos sensores (PARADELLA et al., 1997). A imagem TM-Landsat, após o procedimento de ortorretificação, baseado nos valores de erro médio, ficou com um tamanho de pixel igual a 30 metros. Dessa forma, a imagem geofísica (que será integrada com a imagem TM) foi reamostrada para 30 metros, de modo a equalizála com a imagem TM (HARRIS; MURRAY; HIROSE, 1990, HARRYS et al., 1994; ROLIM, 1993; DIAS; PARADELLA, 1997, SANTOS, 1999).

Posteriormente foi realizado o processamento dessas imagens, que envolve o realce e a geração do produto integrado TM e contagem total, através do método de integração digital IHS.

Na imagem TM foi realizada a transformação por componentes principais (CP), para se destacar as feições de relevo e drenagem da imagem, utilizando-se o primeiro componente principal. Com relação à imagem gama (contagem total), foi realizado o realce linear e a aplicação da tabela de pseudocores, que associa cada nível de cinza a uma cor discreta (RGB), facilitando a interpretação geológica no produto integrado final, uma vez que o sistema visual humano é mais sensível à variação de cores do que aos níveis de cinza.

Existem várias téenicas para combinar dados digitais: as transformações estatísticas e aritméticas e as transformações visuais de cores no monitor de vídeo. As transformações estatísticas e aritméticas, como componentes principais, análise canônica e operações aritméticas possuem um problema relacionado à dificuldade de se obter uma interpretação quantitativa e qualitativa do produto final (imagens de composição colorida), devido às propriedades estatísticas dos dados terem sido manipuladas de modo a ter perda da integridade original dos dados (HARRIS; MURRAY; HIROSE, 1990).

A transformação visual de cores no monitor de vídeo (como a transformação IHS) pode ser usada para produzir apresentações visuais mais efetivas e controladas por procedimentos de interpretação qualita- tiva e quantitativa. A transformação IHS tem sido muito utilizada por obter bons resultados na interpretação geológica. Dessa forma, por ser a mais flexível e que apresenta o melhor desempenho para combinação e integração de dados geológicos multifontes (HARRIS et al., 1994), foi escolhida a técnica IHS para a integração de dados.

0 espaço de cores conhecido por IHS é uma forma alternativa ao espaço RGB de representação de cores. No espaço IHS, as cores são definidas por três atributos (ao invés de três quantidades de cores primárias) que são: Intensidade (Intensity-I), Matiz (Hue-H) e Saturação (Saturation-S).

A integração da imagem TM e a contagem total foram feitas da seguinte maneira:

a) Geração das tabelas de pseudocores para 0 canal de contagem total e convers̃ão para o espaço RGB;

b) Transformação RGB para IHS, através do modelo hexacônico, utilizando-se os canais obtidos no item a;

c) Substituiçã̃o dos canais Intensidade (I) pela imagem TM-Landsat 5 (10 componente principal - (P) realçada linearmente; Saturação (S) por um valor constante (nível de cinza $=40$ ) e manutenção do canal de Matiz (H) original;

d) Retorno ao espaço RGB, através da aplicação da transformação inversa IHS para RGB.

A imagem TM funciona como o produto-base para a integração, pois apresenta feições texturais de relevo e drenagem. Dessa maneira, 0 produto integrado TM-gama apresenta informações gamaespectrométricas, representadas pelos matizes e as informações texturais de relevo e drenagem fornecidas pela imagem $T M$.

\section{Interpretação Fotogeológica}

0 método interpretativo utilizado foi o sistemático, desenvolvido por Rivereau (1970) e Soares e Fiori (1976) e adaptado para imagens de satélite por Veneziani e Anjos (1982). Para a elaboração do mapa geológico, além das feições de relevo e drenagem analisadas na imagem TM, que são indicativas de estruturas tectônicas e contatos litoestruturais, foram consideradas também, na delimitação desses contatos e na discriminação das litologias, as respostas radiométricas do canal de contagem total.

Os pontos de campo foram plotados no produto integrado, auxiliando na interpretação e funcionando como um parâmetro importante na discriminação das unidades litoestruturais do mapa geológico final, assim como as feições de relevo e drenagem fornecidas pela imagem TM que indicam importantes feições estruturais (zonas de cisalhamento, rampas e cavalgamentos). 
Após a delimitação das unidades litoestruturais, é necessária uma avaliação quantitativa a respeito da influência da resposta radiométrica pela atividade antrópica, relevo, entre outras. 0 método utilizado envolve a elaboração de dois perfis (E-W), um geológico-topográfico e outro referente aos valores de contagem total, e a comparação entre eles.

\section{RESULTADOS E DISCUSSÕES}

\section{Interpretação dos produtos integrados $1^{\circ}$ CP TM e contagem total (TM-CT)}

A delimitação das unidades litoestruturais no produto integrado, incluindo os contatos, que na área estudada são tectônicos, levou em consideração não somente as respostas radiométricas fornecidas pelas imagens gama, mas principalmente as feições texturais de relevo e drenagem fornecidas pela imagem TM e analisadas conjuntamente no produto integrado TM-Contagem Total.

Foi elaborado um mapa fotogeológico e posteriormente, com a utilização dos dados de campo (já especificados no item 3) foram discriminadas as litologias da área de estudo. A Figura 5 apresenta o produto integrado TM e contagem total, com a interpretação geológica feita a partiri das feições texturais da imagem TM e dos valores radiométricos de contagem total.

A diferenciação das unidades litoestruturais foi possível, pois com a sua composição mineralógica e os graus de deformação e metamorfismo, chegou-se a respostas radiométricas e em alguns casos, morfologias distintas. A Figura 6 apresenta o mapa geológico elaborado a partir do produto integrado TM-contagem total e dados de campo.

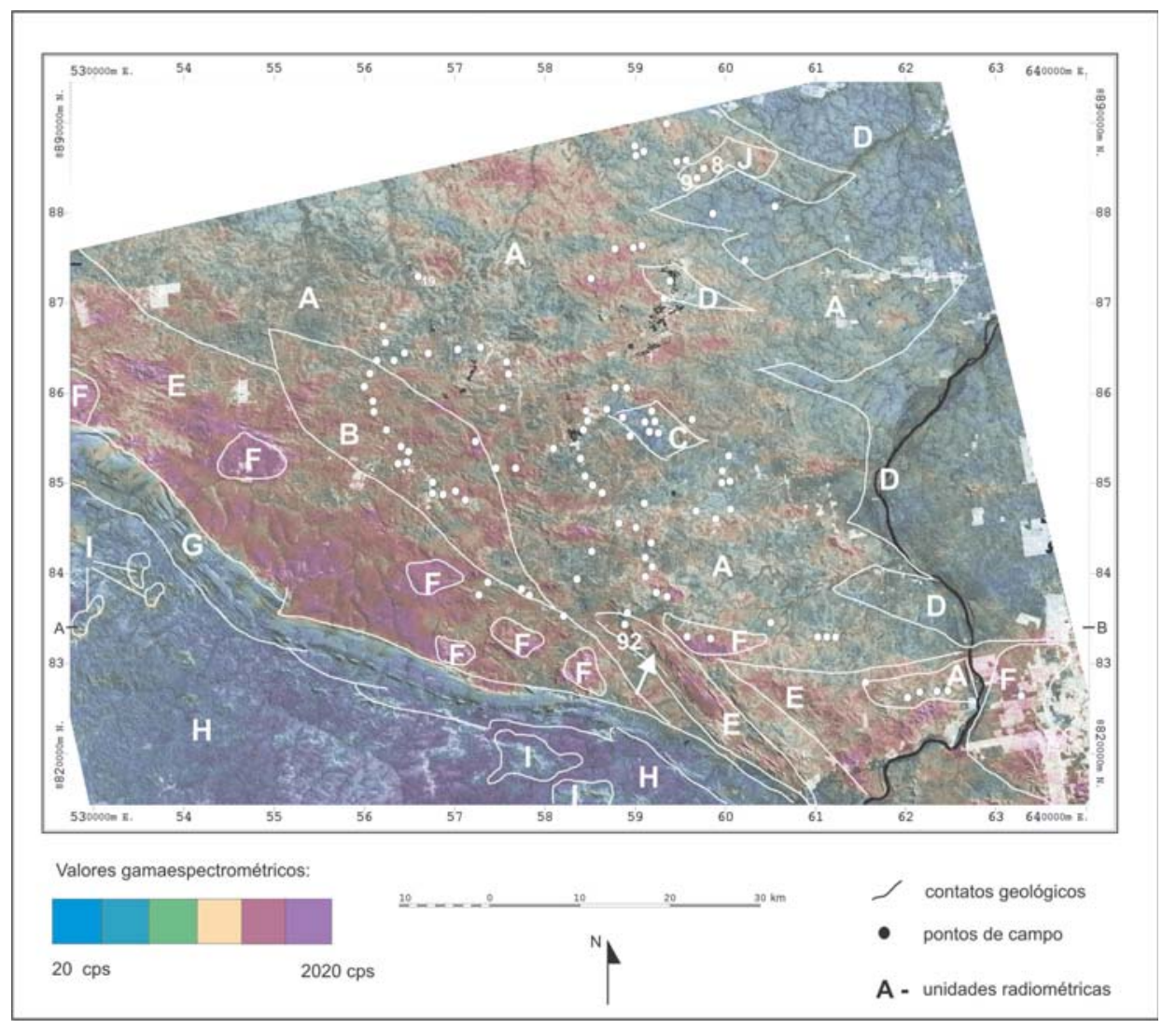

Figura 5 - Produto integrado TM-Landsat 5 ( $1^{\circ}$ Componente Principal) e contagem total (cps).

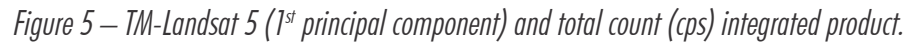




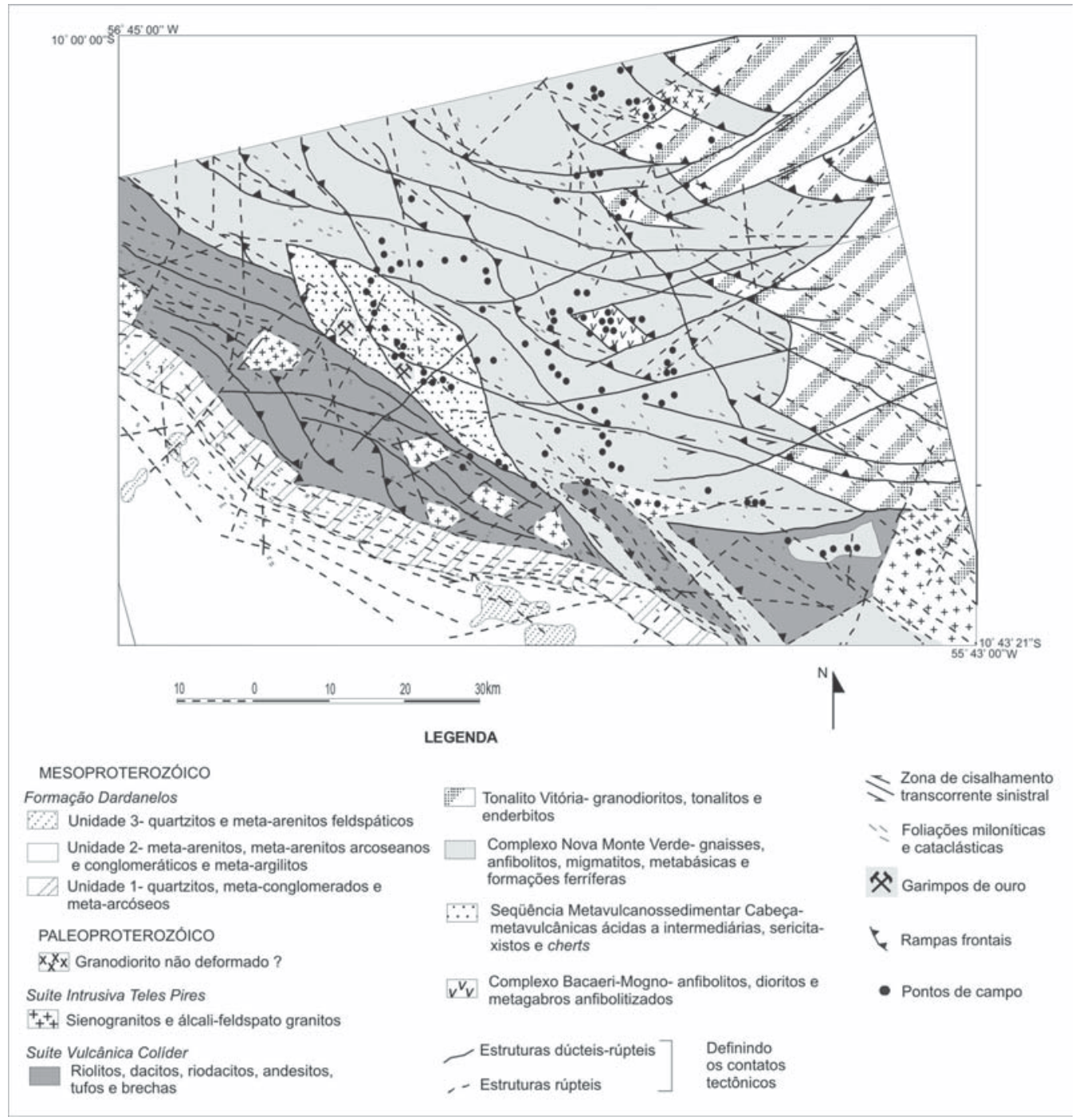

Figura 6 - Mapa geológico elaborado a partir do produto integrado TM-contagem total e dados de campo. Figure 6 - Geological map based on TM-total count integrated product and field data.

Como apresentado nas figuras 5 e 6, foi possível diferenciar 10 unidades litoestruturais (descritas a seguir), que se relacionam diretamente com as unidades radiométricas e com os dados de campo.

\section{- Complexo Bacaeri-Mogno}

As rochas pertencentes ao Complexo Bacaeri-Mogno, representadas pela letra C, são caracterizadas pelas baixas respostas radiométricas (matizes azulados), apresentando valores de média e desvio-padrão iguais a 301,37 cps e 140,35 cps, respectivamente. Esse conjunto de rochas é formado por anfibolitos, dioritos e metagbros anfibolitizados, deformados, apresentando foliações miloníticas. 0 contato com as rochas do Complexo Nova Monte Verde é tectônico, através de zonas de cisalhamento transcorrentes e rampas frontais (cavalgamentos ou empurrões). 


\section{- Seqüência Metavulcanossedimentar do Cabeça}

A unidade radiométrica $B$ representa a sequência metavulcanossedimentar do Cabeça. É formada por rochas metavulcânicas ácidas a intermediárias, sericita xistos, quartzo milonitos e cherts. Devido a sua composição ácida a intermediária e ao grau de deformação rúptil-dúctil apresenta uma resposta radiométrica moderada, variando dos matizes verde ao vermelho (média: 812,44 cps e desvio-padrão: 182,89 cps). As relações de contatos com as unidades circunvizinhas são tectônicas, através de zonas de cisalhamento transcorrentes sinistrais, de direção N60-70W e cavalgamentos.

\section{- Complexo Nova Monte Verde}

0 Complexo Nova Monte Verde (representado pela letra A) possui respostas radiométricas moderadas a altas com valores de média e desvio-padrão iguais a 535,24 cps e 160,20 cps, respectivamente, representadas pelos matizes amarelados aos avermelhados. A diversidade nas respostas é decorrente das variaç̧es petrográficas que incluem desde termos básicos até ácidos (anfibolitos, rochas gnáissicas, granitóides).

Os pontos de campo e as feições estruturais interpretadas a partir da imagem TM auxiliaram na diferenciação deste complexo. As rochas gnáissicas do Complexo Nova Monte Verde, apesar de possuírem uma composição granítica, exibem valores relativamente baixos com relação às respostas de granitos com composição semelhante não-deformados. Observou-se que quanto maior a taxa de deformação dúctil mais baixos são os valores das respostas radiométricas.

As rochas do Complexo Nova Monte Verde apresentam-se bastante deformadas, com presença de foliação miloníitica. 0 contato entre as rochas do Complexo Nova Monte Verde e as rochas granodioríiticas pertencentes ao Tonalito Vitória é tectônico, através de zonas de cisalhamento transcorrentes sinistrais (direção N60-70W) e rampas frontais, desenvolvendo feições de cavalgamento.

\section{- Tonalito Vitória e Granodioritos não-deformados}

Os litotipos pertencentes ao Tonalito Vitória puderam ser bem identificados no produto integrado. A Fácies Granodioríitica (representada pela letra D) apresenta valores radiométricos relativamente baixos (matizes azul claro a esverdeados), com valores de média e desviopadrão iguais a 263,84 cps e 128,59 cps, respectivamente, pois possuem baixa quantidade de álcalis na sua composição e intensa deformaçãa dúctil, embora inclua núcleos menos afetados pelo cisalhamento que constituem os corpos de granodioritos não-deformados (J). Observados em campo (pontos 8 e 9), puderam ser diferenciados do Tonalito Vitória, por apresentarem uma resposta radiométrica um pouco mais elevada (média igual a 574,75 cps e desvio-padrão igual a 148,78 cps) do que as rochas dessa unidade.

Os granodioritos pertencentes a0 Tonalito Vitória possuem pórfiros de plagioclásio com orientação N60-70W (paralelos à foliação milonítica). 0 contato com as outras unidades é tectônico, através de zonas de cisalhamento transcorrentes e rampas frontais.

\section{- Suíte Vulcânica Colíder e Suíte Intrusiva Teles Pires}

As rochas pertencentes a Suíte Vulcânica Colíder e Suíte Intrusiva Teles Pires possuem as mais elevadas respostas radiométricas, da área de estudo (correspondentes aos matizes vermelho e magenta) devido à composição graníitica e por apresentarem deformações essencialmente rúpteis. Elas são facilmente discriminadas entre si.

As rochas vulcânicas (riolitos) e piroclásticas de composiçõo ácida a intermediária com textura fina da Suíte Vulcânica Colíder (unidade E) apresentam uma resposta radiométrica relativamente mais baixa (valores de média e desvio-padrão iguais a 968,29 cps e 254,80 cps, respectivamente) do que os granitos anorogênicos da Suíte Intrusiva Teles Pires (unidade F), representado principalmente por sienogranitos (média igual a 2111,84 cps e desvio-padrão igual a 434,95 cps). Além disso, em alguns locais, os granitos anorogênicos da Suíte Intrusiva Teles Pires sobressaem na morfologia em relação às encaixantes, pois apresentam uma textura diferente na imagem.

0 contato das rochas pertencentes a Suíte Vulcânica Colíder com as outras unidades é tectônico, através de zonas de cisalhamento e rampas com as rochas do Complexo Nova Monte Verde, Metavulcanossedimentares e as rochas da Formação Dardanelos e através de estruturas rúpteis com as intrusões graníiticas do tipo Teles Pires.

Os granitos Teles Pires, por não apresentarem deformação, são considerados anorogênicos. São intrusivos nas rochas da Suíte Vulcânica Colíder, através da reativação das antigas zonas de fraqueza crustal por processos distensivos, sendo as fraturas os contatos tectônicos entre essas unidades.

\section{- Formação Dardanelos}

A Formação Dardanelos foi subdividida em três unidades: unidade 1 consitituída por quartzitos, meta-arcóseos e meta-conglomerados; unidade 2 constituída por meta-arenitos, meta-arenitos arcoseanos, meta-arenitos conglomeráticos e meta-argilitos; e unidade 3 constituída por meta-arenitos e meta-arenitos feldspáticos. Analisando-se o pro- 
duto integrado, nota-se uma morfologia bem diferenciada entre as três unidades.

As cristas alongadas da unidade 3 são reflexos da verticalização das rochas em consequêencia do cisalhamento transcorrente sinistral. 0 contato entre as unidades 1 e 2 é teccônico, seguindo a direção N70W e mergulho vertical. 0 contato geológico entre os quartzitos da Formação Dardanelos e os riolitos da Suíte Vulcânica Colíder é bem evidente, através de uma zona de cisalhamento transcorrente sinistral, com orientação N60-70W.

Os quartzitos da unidade 1 da Formação Dardanelos (representados pela letra $\mathrm{G}$ ) possuem valores radiométricos baixos (matizes azuis), com valores de média e desvio-padrão iguais a 173,55 cps e 155,96 cps, sendo bem diferenciados dos riolitos pertencentes a Suíte Vulcânica Colíder (unidade E) e dos arenitos da unidade 2 (letra H) devido à resposta radiométrica baixa e ao relevo acentuado. Os meta-arenitos, metaarenitos arcoseanos e meta-argilitos, pertencentes à unidade 2 (letra H) da Formação Dardanelos também são bem caracterizados por apresentarem respostas radiométricas baixas (média igual a 199,18 cps e desvio-padrão igual a 85,17 (ps).

Os quartzitos e arenitos feldspáticos pertencentes à unidade 3 da Formação Dardanelos, representados no produto integrado pela letra I, são diferenciados da unidade anterior por apresentarem uma resposta um pouco mais alta do que esta (matizes esbranquiçados a amarelados), valores de média e desvio-padrão iguais a 337,14 cps e 142,36 cps e por possuírem um relevo residual com topo tabuliforme.

Destaca-se nessa interpretação um fato interessante: a unidade radiométrica $\mathrm{E}$ (Figura 5, indicada pela seta) tinha sido interpretada por Valente (1998) como constituída por quartzitos da Formação Dardanelos, pois apresenta um relevo semelhante a esta formação (mapeada a sudoeste da área de estudo), porém sua resposta radiométrica é muito maior (matizes avermelhados) do que a apresentada pelos quartzitos (matizes azuis). Portanto, a resposta radiométrica indica que não se tratam das mesmas litologias. A verificação de campo (ponto 92) comprovou que a área individualizada como E é composta por riolitos (provavelmente da Suíte Vulcânica Colíder) e não quartzitos.

Segundo Matolin (1984), a radioatividade das rochas ígneas tende a aumentar com a acidez dos magmas, isto é, com o aumento de $\mathrm{SiO}_{2}$. Dessa forma, rochas ácidas apresentarão maiores respostas radiométricas de $\mathrm{U}, \mathrm{Th}, \mathrm{K}$ e $\mathrm{CT}$ do que rochas intermediárias, básicas e ultrabásicas.

Em relação às rochas sedimentares, a radioatividade está relacionada com o material que foi depositado, com a mobilidade do $\mathrm{U}$ e $\mathrm{Ke}$ a insolubilidade do Th. Folhelhos e argilas apresentam maiores valores radiométricos, seguido de arenitos e calcários que apresentam valores

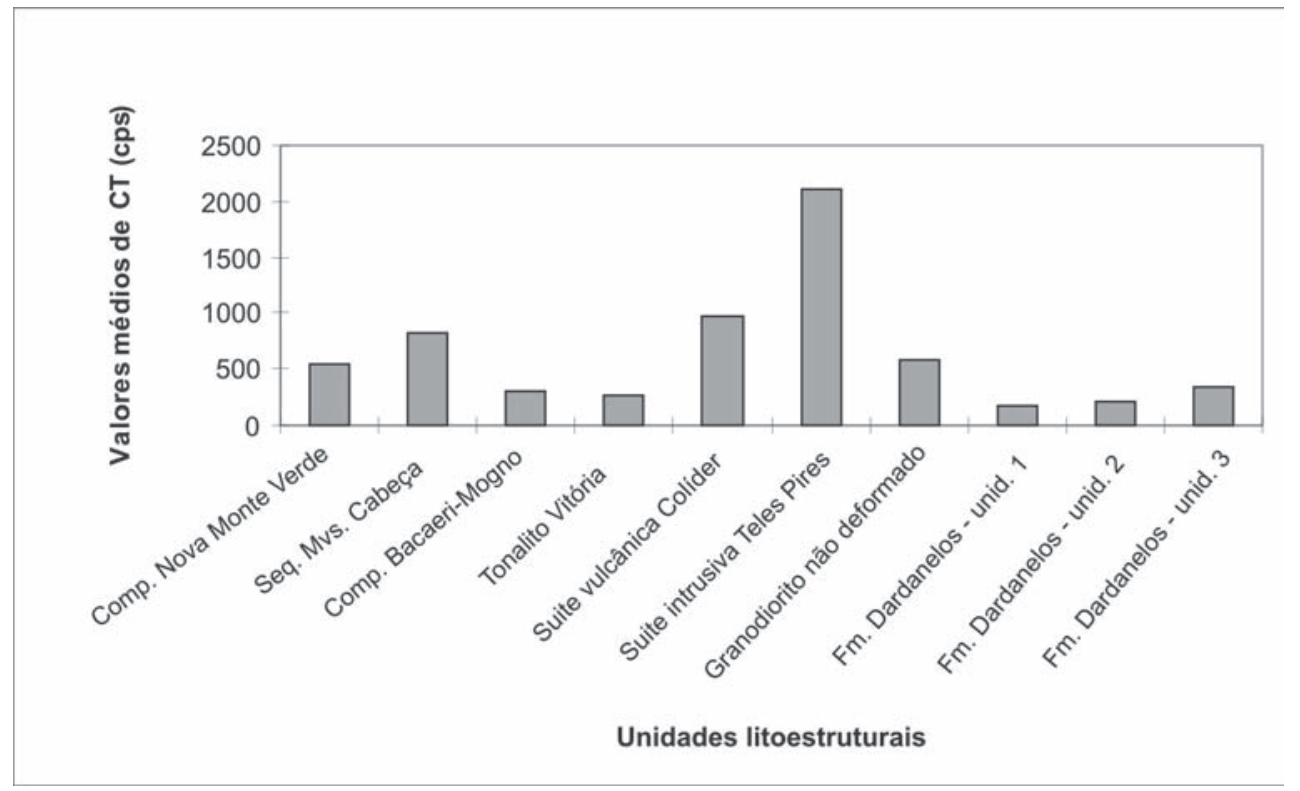

Figura 7 - Valores médios de contagem total (cps) das unidades litoestruturais mapeadas. Figure 7 - Total count average values (cps) of identified lithostructural units. 
mais baixos. Os valores radiométricos das rochas ígneas ácidas são bem mais elevados do que os valores de rochas sedimentares, como os arenitos, apesar de ambas serem ricas em sílica. A Figura 7 apresenta um gráfico com os valores médios de contagem total, em cps, para cada uma das unidades litoestruturais mapeadas.

\section{INTERPRETAÇÃO DOS VALORES RADIOMÉTRICOS NOS PRODUTOS INTEGRADOS}

Muitos fatores interferem nas respostas gamaespectrométricas, além do tipo de rocha: relevo, vegetação, solo exposto, etc. Segundo Gunn e outros (1988), a topografia e a ocupação variável no terreno podem causar erros nos processamentos dos dados, pois 0 algoritmo utilizado considera um terreno constante e uma superfície plana. Bicho (1994), estudando a região de Rondônia, através de imagens orbitais integradas com dados aerogeofísicos, constatou que existe uma alta correlação entre as anomalias radiométricas (imagens gama) e outros fa- tores, tais como ausência de cobertura vegetal, existência de rochas expostas, altos topográficos e atividades antrópicas.

Para verificar se estes fatores estavam influenciando as respostas na área de estudo, foi elaborado um perfil A-B (oeste-leste) dos valores radiométricos, em cps, referentes à contagem total, através do mapa de isolinhas de valores radiométricos e um perfil geológico topográfico $A-B$, contendo as localizações das atividades antrópicas observadas na imagem TM (composiçã̃o colorida: RGB 543), cuja data de aquisição pelo satélite é a mesma do aerolevantamento geofíisico (1991). As figuras 7 a e $7 \mathrm{~b}$ apresentam os dois perfis respectivamente.

Analisando-se estas figuras observa-se nitidamente que os valores radiométricos estão relacionados ao tipo de rocha. A atividade antrópica, neste caso, não está influenciando os altos valores radiométricos, pois nos poucos locais onde ela ocorre, existe associação com baixos e altos valores radiométricos.

Observa-se que os altos valores radiométricos (em torno de 850 cps) não têm relação direta com as regiões de relevo mais acidentado

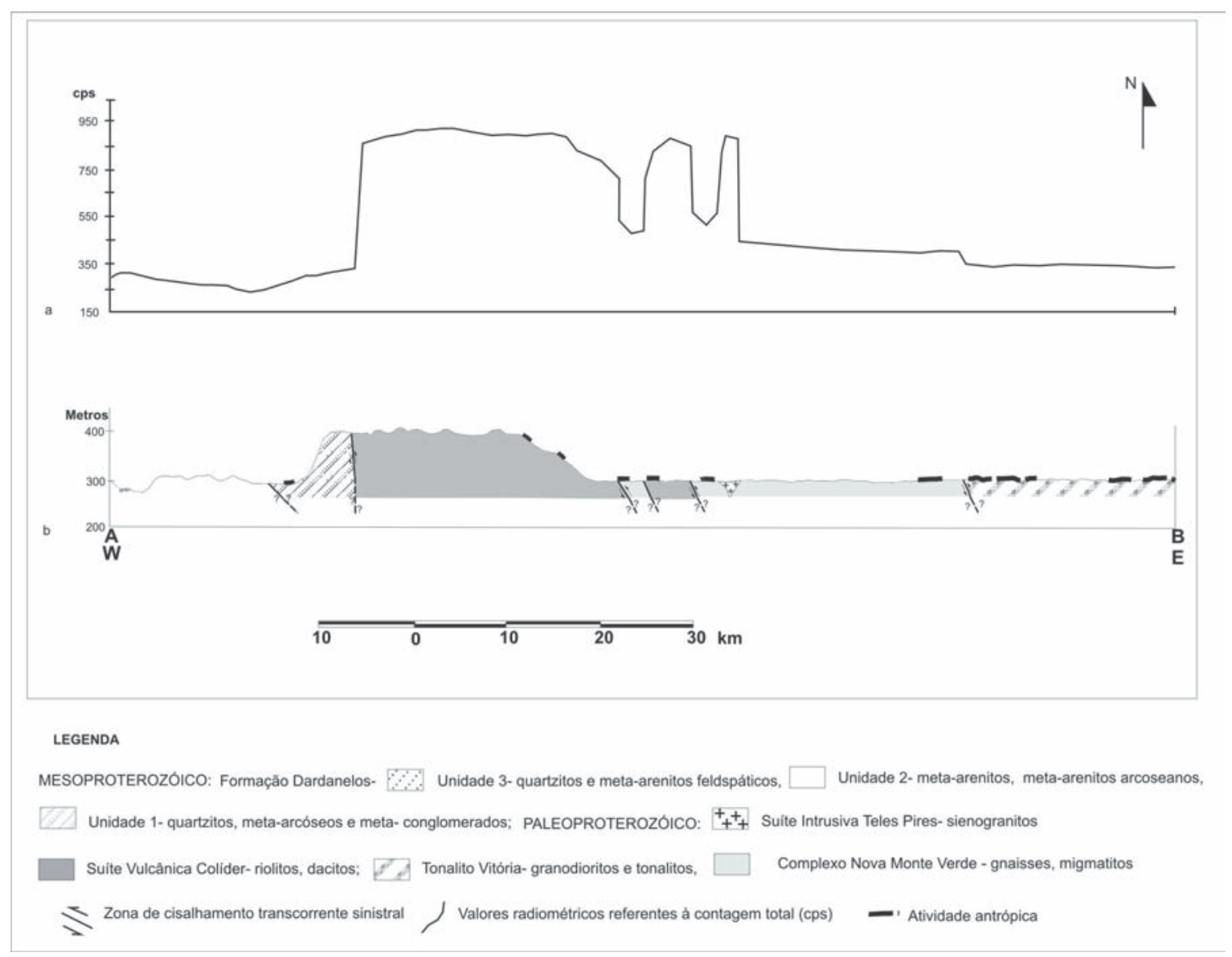

Figura 8 a - Perfil gamaespectrométrico A-B (W-E) referente ao canal de contagem total (cps). Figure $8 a-$ Gamma ray spectrometric profile $A-B(W-E)$ referring to total count channel (cps). 


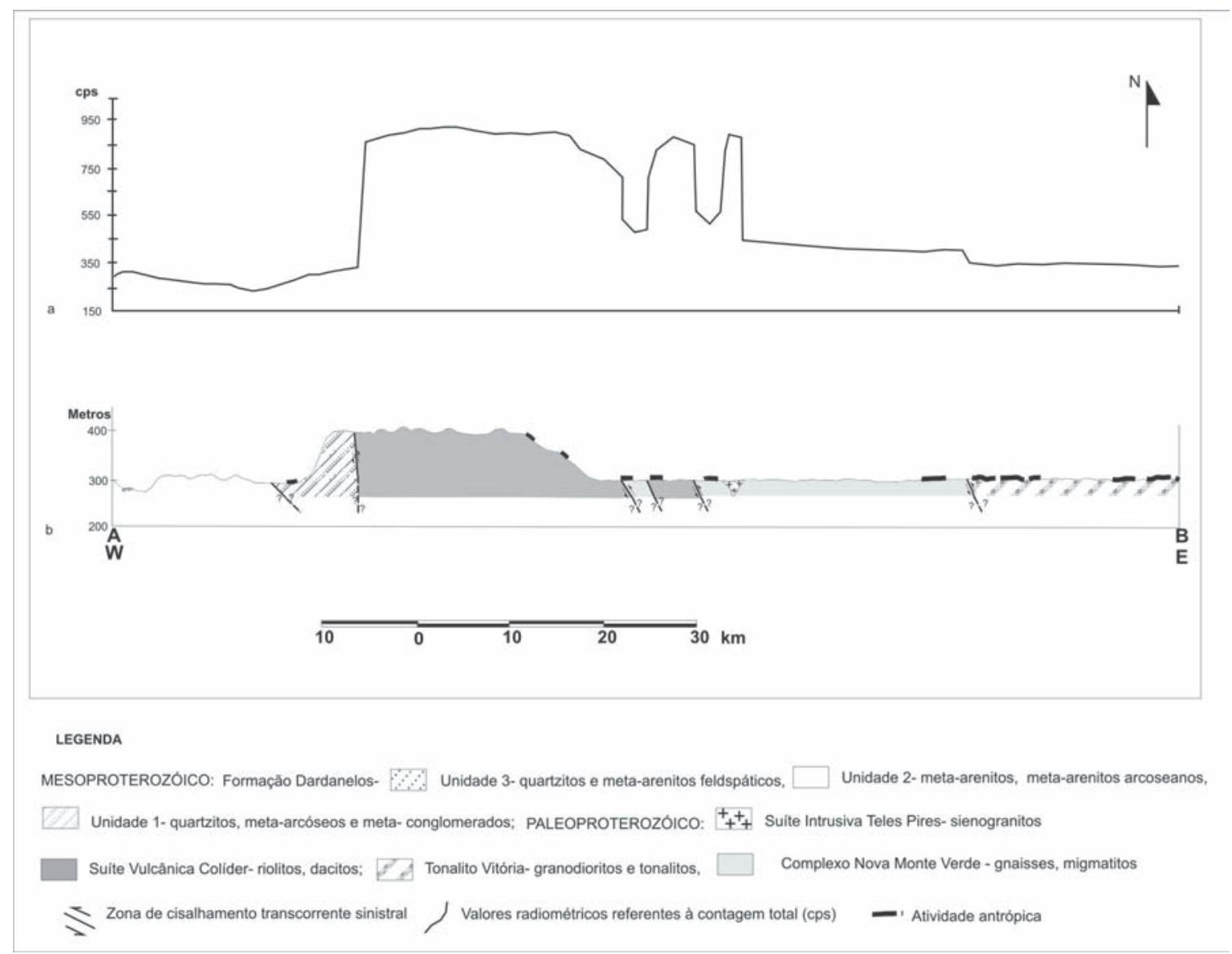

Figura 8 b - Perfil geológico.

Figure $8 b$ - Geological profile.

(400 metros). Tais valores radiométricos correspondem aos riolitos do Suíte Vulcânica Colíder. As rochas quartzíticas da Formação Dardanelos, que também fazem parte da região topográfica mais proeminente, apresentam valores radiométricos baixos (300 cps).

Na região topograficamente mais arrasada, observou-se que existem variações nas respostas radiométricas de acordo com as variações litológicas, como por exemplo, os riolitos e granitos apresentam altas respostas; as rochas do Complexo Nova Monte Verde (gnaisses) apresentam valores baixos a moderados (450 cps); as rochas granodioríticas pertencentes ao Tonalito Vitória valores baixos (300 cps) e, as rochas metassedimentares da Formação Dardanelos apresentam os valores radiométricos mais baixos da área (250 cps), tornando evidente que, para a área de estudo, a geologia (tipos de rochas) controla as respostas gamaespectrométricas, independentemente do relevo, da existência de cobertura de solos e da atividade antrópica.

\section{EVOLUÇÃO TECTÔNICA DA ÁREA}

Segundo Valente (1998), Madrucci (2000), Madrucci e outros (2002) estes dois últimos baseados na interpretação do produto integrado TM-CT e dados de campo, a principal e mais proeminente deformação tectônica da área é atribuída ao evento compressivo, com direção de máximo esforço compressivo $\left(\sigma_{1}\right)$ em torno de $N 80^{\circ} E$ que afetou de modo generalizado a região e foi responsável pelo desenvolvimento de zonas de cisalhamento transcorrentes sinistrais, com direções $\mathrm{N} 60^{\circ}$ $70^{\circ} \mathrm{W}$, de natureza dúctil a dúctil-rúptil e demais estruturas associadas, tais como rampas frontais, oblíquas, sistemas sintéticos e antitéticos. Esse conjunto de estruturas representa o fenômeno de cisalhamento simples, em um evento de deformação progressiva, que é comprovado nas imagens de satélite através das observações de feições de arrasto dúctil e também observaç̃oes feitas em campo, como foliações miloníticas, 
desenvolvimento de estiramento mineral, veios de quartzo estirados (indicando movimento direcional), veios de quartzo dobrados na forma de Z, transversais a foliação (indicando movimento sinistral para a direção da zona de cisalhamento dúctil), eeições de cavalgamento, etc.

Este evento compressivo teria ocorrido no período Paleoproterozóico - Rhyaciano (em decorrência de as rochas mais antigas da área apresentarem idades de 2,24 Ga) até aproximadamente $1786 \mathrm{Ma}$, (que é a pré-idade dos granitos anorogênicos pertencentes à Suíte Intrusiva Teles Pires).

A intensa deformação de caráter dúctil, dúctil-rúptil (provocada pelo evento compressivo com $\sigma_{1}$ em torno de $\mathrm{N} 80^{\circ} \mathrm{E}$ ) é evidenciada nas rochas dos Complexos Bacaeri-Mogno, Sequiência Metavulcanossedimentar Cabeça, Complexo Nova Monte Verde, Tonalitos Vitória e Suíte Vulcânica Colíder pela foliação milonítica muito proeminente, e, no caso dos granodioritos (Tonalitos Vitória), pela orientação dos pórfiros de plagioclásio segundo a direção N60\% (paralela à foliação miloníitica). A partir dessa idade, passaram a predominar movimentos transtensivos na área, provocando reativaçôes das antigas zonas de fraqueza crustal, favorecendo a intrusão das rochas pertencentes à Suíte Intrusiva Teles Pires (MADRUCCI, 2000; MADRUCCl; VENEZIANI; PARADELLA, 2002).

A Formação Dardanelos está deformada também, porém de modo predominantemente rúptil (foliações cataclásticas) e verticalizada nas proximidades dos contatos com a Suíte Vulcânica Colíder, o que também indica um movimento transtensivo anterior, que criou as condições favoráveis para o alojamento dos granitos anorogênicos e para a formação da bacia onde foram depositados os sedimentos da Formação Dardanelos.

Da mesma maneira que Madrucci (2000) e Madrucci, Veneziani e Paradella (2002), Lacerda Filho e outros (2001a) também identificaram um domínio dúctil e um domínio rúptil na região estudada. 0 domínio dúctil está associado às rochas de médio a alto grav e mostra estilo deformacional progressivo compressional de SW para NE, culminando com uma zona de underthrust colocando terrenos de alto grau sob as suítes plutono-vulcânicas pouco deformadas. Zonas de cisalhamento dúctil NW-SE e EW quilométricas, com cinemática conjugada sinistral e dextral transpressionadas e oblíquas são dominantes (LACERDA FILHO et al., 2001a).

0 domínio rúptil-dúctil representa os terrenos pouco deformados do DGV e coberturas sedimentares proterozóicas. É caracterizado pela presença de zonas de cisalhamento centimétricas a métricas, na maioria das vezes descontínuas, formadas a partir da nucleação de fraturas e/ou falhas com direções NW-SE e EW com cinemática transcorrente sinistral e NS dextral. São desenvolvidas a partir de um sistema compressivo, com $\sigma_{1}$ em torno de $\mathrm{N} 50^{\circ}$ E. Nestas descontinuidades tectônicas alojaram-se as principais mineralizações auríferas na região (LACERDA FILH0 et al., 2001a).

\section{CONCLUSÕES}

A integração digital da imagem TM e gama pelo método IHS mostrou-se excelente para o mapeamento geológico. 0 produto integrado final apresenta as feições texturais de relevo e drenagem e as variações de matizes referentes às repostas radiométricas, permitindo a realização de uma fotointerpretação ainda mais completa, com a melhor delimitação das unidades litoestruturais. Dessa maneira, os contatos geológicos, neste produto, não são apenas definidos nas respostas radiométricas e sim, de maneira conjunta com as informações texturais fornecidas pela imagem TM.

0 produto integrado TM-gama mostrou-se muito útil para mapeamentos geológicos regionais e de detalhe na região amazônica, que é uma região de difíicil acesso e pouco estudada geologicamente. Mas é preciso que se verifique a influência de vegetação, topografia, solo exposto, através de análises quantitativas das respostas radiométricas, para que não sejam realizadas interpretações errôneas a respeito da geologia do local.

Rochas de mesma composição mineralógica, porém com diferentes graus de deformação, apresentam respostas radiométricas distintas. Quanto maior 0 grau de deformação, menor a resposta radiométrica.

A análise quantitativa feita através dos perfis geológico/topográfico e radiométrico (contagem total) mostrou que, na área de estudo, a resposta radiométrica de contagem total está diretamente relacionada com a composição química e mineralógica das rochas. Nem a presença de atividade antrópica e nem a variação de relevos mascararam 0 papel controlador da litologia nas respostas gamaespectrométricas.

A área sofreu deformações dúctil, dúctil-rúptil e rúptil (até aproximadamente 1786 Ma, que é a pré-idade dos granitos anorogênicos pertencentes à Suíte Intrusiva Teles Pires), com a existência de um evento tectônico compressivo, que gerou uma zona de cisalhamento transcorrente sinistral, não-coaxial, de direção N60-70W, em uma área com deformação progressiva. Esse evento originou a formação de uma bacia romboédrica, com estruturas do tipo duplex. As evidências encontradas durante a interpretação dos produtos integrados bem como as obtidas em campo indicam que a área estudada localiza-se de uma estrutura como a citada. Posteriormente esta área sofreu esforços distensivos, que reativaram as antigas zonas de fraqueza crustal geradas pelo último evento compressivo, favorecendo a intrusão dos granitos pertencentes à Suíte Intrusiva Teles Pires.

0 grau de confiabilidade do mapa geológico (na escala 1:250.000) gerado a partir deste produto integrado pôde ser comprovado pelos dados de campo. Esses dados confirmam as interpretações 
feitas e reforçam a importância do uso de produtos integrados TM e gama no mapeamento geológico de áreas similares à desta pesquisa.

\section{Agradecimentos}

Os autores agradecem aos geólogos Cidney Rodrigues Valente (CPRM) e Antonio João Paes de Barros (METAMAT), pelo fornecimento de dados de campo e mapas geológicos; à Companhia de Pesquisa de Recursos Minerais (CPRM/Rio de Janeiro), nas pessoas de Maria Laura Vereza de Azevedo e Mário José Metello, pelo fornecimento dos dados aerogeofííicos gamaespectrométricos, referentes ao Projeto Juruena-Teles Pires; a Instituto Nacional de Pesquisas Espaciais (INPE); à Universidade de São Paulo-Instituto de Geociências, pelo suporte técnico e ao Conselho Nacional de Desenvolvimento Científico e Tecnológico (CNPq), na forma de bolsa de mestrado concedida ao primeiro autor.

\section{REFERÊNCIAS}

BARROS, A. J. P.; LAET, S. M.; RESENDE, W. M. Províncias auriferas do norte do estado do Mato Grosso. In: SIMPÓSIO DE GEOLOGIA DA AMAZÔNIA, 6., 1999, Manaus. Boletim de Resumos Expandidos... Manaus: [s.n.], 1999. v. 1. p. 124-127.

BASEI, M. A. S. Idade do vulcanismo ácido-intermediário na região Amazônica. 1977. Dissertação (Mestrado)-Instituto de Geociências, Universidade de São Paulo, São Paulo, 1977.

BICHO, P. C. Processamento digital de imagens aerogeofísicas, landsat/ TM e radar na folha Presidente Médice/RO, com ênfase na caracterização metalogenética da suíte granítica Rio Pardo. 1994. Dissertação (Mestrado)-Instituto de Geociências, Universidade Federal de Campinas, Campinas, 1994.

DIAS, R. R.; PARADELLA, W. R. Integração de dados aéreos gamaespectrométricos com imagens TM-Landsat no mapeamento geológico da área do Pojuca, província mineral de Carajás. Revista Brasileira de Geofísica, [S.I.], v. 15, n. 1, p. 23-33, 1997.

LACERDA FILHO, et al. Geologia e evolução tectônica da região norte do Mato Grosso - Projeto Promin-Alta Floresta. In: SIMPÓSIO DE GEOLOGIA DA AMAZÔNIA, 7., 2001, Belém. Resumos Expandidos... Belém: [s.n], 2001a. CD-ROM.

LACERDA FILHO, et al. Geocronologia U-Pb e Sm-Nd da região de Alta Floresta, norte de Mato Grosso. In: WORKSHOP ON GEOLOGY OF THE SW AMAZONIAN CRATON: STATE-OF-THE-ART, 2001, [S.I.]. Extended abstract... [S.I.: s.n.], 2001 b. p. 53.

GUNN, P. et al. Interpretation of airborne magnetic and radiometric surveys. Camberra: Australian Geological Survey Organisation- AGSO, 1998. Airborne geophysics group.
HARRIS, J. R. et al. Computer-enhancement techniques for the integration of remotely sensed, geophysical, and thematic data for the geosciences. Canadian Journal of Remote Sensing, [S.I.], v. 20, n. 3, p. 210-221, 1994.

; MURRAY, R.; HIROSE, T. IHS transform for the integration of radar imagery and other remotely sensed data. Photogrammetric Engineering and Remote Sensing, [S.I.], v. 56 n. 12, p. 1631-1641, 1990.

LEITE, J. A. D.; SAES, G. S.; MACAMBIRA, M. J. B. „,The Southwest portion of Amazon Cráton in Mato Grosso State, Brazil: the state-of-art of geology knowledge. In: WORKSHOP ON GEOLOGY OF THE SW AMAZONIAN CRATON: STATE-OF-THE-ART, 2001, [S.I.]. Extended abstract...[S.I.s.s..], 2001. p. 64-65p.

MADRUCCI, V. Avaliação dos produtos integrados TM-Landsat, RADARSAT e gamaespectrométricos, na caracterização tectônica e mapeamento geológico de área mineralizada em ouro na região de Alta Floresta MT. Dissertaçãa (Mestrado)-Instituto Nacional de Pesquisas Espaciais, São José dos Campos, 2000.

; VENEZIANI, P.; PARADELLA, W. R. Estudo estrutural através da interpretação de imagens TM-Landsat 5 e sua associação com mineralizações auríferas em Alta Floresta, Mato Grosso. In: KLEIN, Evandro Luiz et al (Org.). Contribuições à Geologia da Amazônia, vol. 3. Belém: [s.n.], 2002. v. 3. p. 215-225.

MATOLIN, M. Radiometric methods and methods of nuclear geophysics. In: MARES, Stanislav. Introduction to apllied geophysics. Holland: Dordrecht, 1984. p. 154-231.

MATTER, P. M. Computer processing of remotely-sensed images: an introduction. Chichester: John Wiley, 1987.

OKIDA, R. Aplicação do sensoriamento remoto e aerogamaespectrometria ao estudo do controle estrutural dos granitos estaníferos de Rondônia. Tese (Doutorado)-Instituto de Geociências, Universidade de São Paulo, São Paulo, 2001.

PARADELLA, W. R. et al. Airborne and spaceborne Synthetic Aperture Radar (SAR) integration with Landsat TM and gamma ray spectrometry for geological mapping in a tropical rainforest environment, the Carajas Mineral Province, Brazil. International Journal of Remote Sensing, [S.I.], v.18, n. 7, p. 483-1501, 1997.

PINHO, M. A. S. B.; LIMA, E. F.; CHEMALE, J. F. Caracterização das rochas vulcânicas da Formação lriri na região de Moriru-Aripuanã, MT. In: SIMPÓSIO SOBRE VULCANISMO E AMBIENTES ASSOCIADOS, 1., 1999, Gramado. Boletim Resumos...Gramado: [s.n.], 1999. p. 48.

PINHO, M. A. S. B. et al. Discussão do termo Uatumã-lriri, região norte do Estado de Mato Grosso - Brasil. SIMPÓSIO DE GEOLOGIA DA AMAZÔNIA, 7., 2001, Belém. Resumos Expandidos... [S.I.: s.n], [2001]. CDROM. 
RENCZ, A. N.; RYERSON, R. A. Manual of remote sensing: remote sensing for earth sciences. Danver: Wiley and Sons, 1999. v. 3. RIVERAU, J.C. Curso de fotointerpretação. In: SEMANA DE ESTUDOS, 11., 1972, Ouro Preto. Fotografia aérea e aplicações técnicas. Ouro Preto: SICEG, 1972. p. 75-121. Notas de aula.

ROLIM, S. B. A. Avaliação do uso da transformação IHS na integração de dados geofísicos (aeromagnetometria) e de sensoriamento remoto (TM Landsat) para a investigação geológica na área do Pojuca (Serra dos Carajás, PA). 1993. Dissertação (Mestrado)-Instituto Nacional de Pesquisas Espaciais, São José dos Campos, 1993.

SANTOS, S. L. C. Integração digital de dados RADARSAT S-1 e aerogamaespectrométricos: contribuição ao estudo de corpos graníiticos mineralizados da província estaniffera de Rondônia. 1999. Dissertação (Mestrado)-Instituto Nacional de Pesquisas Espaciais, São José dos Campos, 1999.

SILVA et al. Geologia: Folha SC. 21 Juruena. Projeto Radambrasil. (Levantamento de Recursos Naturais). Rio de Janeiro, n. 20, 1980.
SOARES, P. C.; FIORI, A. P. Lógica e sistemática na análise e interpretação de fotografias aéreas em geologia. Noticiário Geomorfológico, [S.I.], v.16, n. 32, p. 107-121, 1976.

TASSINARI, C. C. G.; MACAMBIRA, M. J. B. Geochronological provinces of the Amazon Craton. Episodes, [S.I.], v. 22, n. 3, p. 174-182, 1999.

TOUTIN, T. Intégration de donnés multi-source: comparison de méthods géométriques. International Journal of Remote Sensing, [S.I.], v. 16, n. 5, p. 2795-2811, 1995.

VALENTE, C. R. Aspectos geológicos e tectônicos da Província Mineral Alta Floresta - PROMIN: um estudo a partir da utilização de sensoriamento remoto. Rio de Janeiro: Ministério das Minas e Metalurgia, 1998.

VASCONCELLOS, R. M. et al. Geofísica para levantamentos geológicos. Rio de Janeiro: (PRM, 1994.

VENEZIANI, P.; ANJOS, C. E. Metodologia de interpretação de dados de sensoriamento remoto e aplicações em geologia. São José dos Campos: INPE, 1982.

\section{NOTAS SOBRE OS AUTORES}

Vanessa Madrucci é geóloga, formada na UNESP (1996). Mestre em sensoriamento remoto pelo INPE (1999). Atualmente é doutoranda (bolsista FAPESP) na área de Recursos Minerais e Hidrogeologia, no Instituto de Geociências - USP. A linha de pesquisa de interesse é a utilização de dados de sensoriamento remoto (óptico e radar), geofísicos (aeroportados e terrestres) e técnicas de geoprocessamento aplicados ao mapeamento geológico-estrutural, bem como à prospecção mineral e de água subterrânea em terrenos fraturados.

Paulo Veneziani é geólogo pela USP (1973), mestre em Sensoriamento Remoto pelo INPE (1976), doutor em geologia pela USP em 1987. Pesquisador no Instituto Nacional de Pesquisas Espaciais (INPE)- Divisão de Sensoriamento Remoto, desde 1974. Sua linha de pesquisa atual envolve a interpretação geológica de produtos integrados SAR, imagens de sensores ópticos e dados aerogeofísicos com ênfase na análise tectônica e estrutural aplicada à prospecção mineral na Província Estanífera de Rondônia e Província Mineral de Carajás.

Waldir Renato Paradella é geólogo pela USP (1973), mestre em Sensoriamento Remoto pelo INPE (1976), doutor em geologia pela USP (1983) e pós-doutorado no Canadá Centre for Remote Sensing (1988-1989). Pesquisador-titular do INPE com envolvimento, como investigador-principal, em vários programas internacionais na avaliação geológica de sensores ópticos (SPOT-1/PEPS da França) e de radar (SAREX' 92, RADARSAT-1/ADRO e GlobeSAR, todos do Canadá). Atualmente é o investigador-principal na avaliação nas Geociências dos dados do radar PALSAR do satélite ALOS junto à JAXA (Japão), e o responsável pelo segmento de aplicações do MAPSAR, um estudo de viabilidade técnica de um radar orbital em desenvolvimento entre o Brasil (INPE) e a Alemanha (DLR). É bolsista de produtividade em pesquisa pelo CNPq (1B). 